Article

\title{
Governmentality, the Local State, and the Commons: An Analysis of Civic Management Facilities in Barcelona
}

\author{
Marina Pera ${ }^{1,2, *}$ and lolanda Bianchi ${ }^{2}$ \\ ${ }^{1}$ Political Science Department, Autonomous University of Barcelona, Spain \\ 2 Institute for Government and Public Policy (IGOP), Autonomous University of Barcelona, Spain \\ * Corresponding author (marina.pera@uab.cat)
}

Submitted: 24 July 2021 | Accepted: 26 October 2021 | Published: 22 February 2022

\begin{abstract}
This article deploys the Foucauldian concept of governmentality to study the political tensions that may unfold when commons are enacted through hybrid institutional configurations. We focus on civic management facilities (CMFs) that are located in the city of Barcelona. These are facilities owned by Barcelona City Council which, responding to organised citizens' demands, are transferred to them so that they can develop their own transformative projects for the community. The hybrid institutional nature of these CMFs makes it impossible for them to avoid maintaining a relationship with the local state. Based on a survey to $51 \mathrm{CMFs}$, semi-structured interviews with 41 grassroots members of CMFs and seven semi-structured interviews with public employees and politicians, we argue that hybrid forms of commons lead to the development of political tensions. On the one hand, we show how the local state's administrative procedures-to do with accountability and the use of public space-reshape the activities of the CMFs, leading to the depoliticisation of their transformative projects. On the other hand, the analysis also presents the strategies of resistance articulated by the facilities, which enable members to work towards the development of their transformative aims. We conclude that such political tensions cannot be resolved but must be properly governed in order to make the commons' transformative project an enduring one.
\end{abstract}

\section{Keywords}

co-option; depoliticisation; governmentality; grassroots; hybrid commons; local state; participation; qualitative research; strategies of resistance; technologies of power

Issue

This article is a part of the issue "The Politics and Aesthetics of the Urban Commons: Navigating the Gaze of the City, the State, the Market" edited by Peer Smets (Vrije Universiteit Amsterdam) and Louis Volont (Massachusetts Institute of Technology).

(C) 2022 by the author(s); licensee Cogitatio (Lisbon, Portugal). This article is licensed under a Creative Commons Attribution 4.0 International License (CC BY).

\section{Introduction}

Gestió cívica ("civic management") is a legal-political category that includes public facilities-cultural centres, community centres, youth clubs, and more-owned by the city of Barcelona, which is governed by the Barcelona City Council (henceforth City Council), and transferred to the non-profit grassroots organisations that manage them: civic management facilities (CMFs). The city of Barcelona has a wide network of public facilities that are either directly managed by the City Council, out- sourced to private companies, or managed by grassroots organisations, such as CMFs. The emergence of CMFs is related to Barcelona's tradition of self-organisation that created cultural and social centres for providing education and social protection for workers at the end of the 19th century (Bianchi, 2018a; Dalmau \& Miró, 2010) and to neighbourhood struggles that emerged in the 1960 s to demand social transformation in the city (Andreu Acebal, 2014). CMFs act as commons in critical terms (De Angelis, 2018; Federici, 2018; Harvey, 2012), given that these are resources, i.e., facilities, that are self-managed by 
non-profit grassroots organisations that establish their own rules and norms to carry out socially transformative projects. Nevertheless, they represent a very particular type of commons, since the facilities are owned by the City Council, which temporarily cedes their management to the grassroots organisations and provides a yearly financial subsidy to contribute to their functioning and work in the community. In short, CMFs are commoning practices that are enacted through hybrid institutional configurations (Mullins et al., 2018). This hybrid institutional nature means that CMFs maintain ongoing organisational relationships with the local state, which require them to comply with a set of administrative norms and bureaucratic procedures. These hybrid forms of commons are more widespread that is often thought, and we aim to contribute to understanding the types of political tensions that may unfold when commons develop through these hybrid institutional configurations.

In this article, using Foucault's concept of governmentality, we seek to investigate how the City Council's administrative norms and bureaucratic proceduresconcerning accountability and the use of public spaceaffect transformative CMF projects. We understand governmentality as the rationalisation and implementation of power arrangements to align subjects and transform dissidence; this is not applied exclusively by the state, but is also exercised by it (Dean, 1999; Rose, 1999). We also seek to investigate the forms of resistance that are generated and mobilised by CMFs in order to work towards their transformative goals. Adopting a case study method with multiple subcases (Yin, 2014) that investigates CMFs in the city of Barcelona, we use mixed techniques to analyse how the City Council implements public administration procedures and reshapes the activities developed by the CMFs by absorbing members' time and resources, and how different strategies are articulated by CMF members to circumvent this reshaping of their projects. We argue that when commons adopt hybrid institutional configurations, political tensions unfold. Observing the case of CMFs, on the one hand, administrative norms and bureaucratic procedures function as the City Council's technologies of power to depoliticise commons' actions. This is understood as the co-optation of the transformative potential of commons (Mayer, 2013). However, on the other hand, we also show how activists endeavour to create forms of resistance that hinder this form of co-optation.

In this article, we begin with a conceptual section in which we present CMFs as hybrid commons, considering their historical origins in citizen mobilisation. Then we introduce the concept of governmentality, examining how the concept is articulated in the study of power, and we justify the use of it to analyse CMFs. Afterwards we discuss how two different administrative procedures related to accountability and to the use of public space act as technologies of power. We then analyse strategies of resistance aimed at the development of more transformative goals in the CMFs. Finally, we conclude by under- lining the need to explore strategies and modes to govern the idiosyncratic character of hybrid forms of commons and to limit the effects of technologies of power.

\section{Civic Management Facilities as Commons}

Barcelona-and Catalonia in general-has a strong tradition of self-organisation that can be dated back to the beginning of the 19th century, when different selforganised social centres (ateneus populars) were set up to offer cultural and educational opportunities by and for the working class (Solà, 1978). These initiatives were all suppressed by the Franco regime. However, demands for self-organisation resurged in the late 1960s with the emergence of neighbourhood associations that fought to improve living conditions and produce social transformation in the city (Andreu Acebal, 2014). These struggles contributed to the emergence of CMFs in Barcelona. In the transition to democracy, after the dictatorship (the late 1970s), the City Council began creating its own directly-managed network of public cultural and social facilities-e.g., cultural centres, community centres, youth clubs, and more. Later on, these were progressively and partially outsourced (Sánchez Belando, 2015). The neighbourhood associations and grassroots organisations demanded the creation of their own self-governing cultural and social spaces, especially in low-income neighbourhoods that had been neglected by the City Council's welfare policy. These struggles led the City Council to hand over the management of some of these facilities to grassroots organisations to develop their own projects (Bianchi, 2018a; García et al., 2015). This type of public facility management was called gestió cívica ("civic management," and thus CMFs). In 2019, the City Council participated in 56 CMFs.

According to the critical theory of the commons, CMFs act like commons. The theory of the phenomenon, which has grown in particular since the second half of the 20th century, has been explored by different disciplines and with varying slants. Among the most relevant currents, it is worth mentioning the neo-institutionalist and the critical approaches (Bianchi, 2018c; Enright \& Rossi, 2018). The neo-institutionalist approach interprets the commons as an alternative management form to that of the state and the market. Neo-institutionalist scholars see the commons as (tangible or intangible) resources that are self-managed by a collective that establishes its own rules and norms (Hess \& Ostrom, 2007; Ostrom, 1990). For its part, the critical approach interprets the commons as self-organised social practicescommoning practices - that, by representing an alternative to that of the state and the market, can represent the means for overcoming both, and can thus open up the possibility of outlining a path of emancipation from capitalism. Critical scholars see the commons as collective activities through which communities govern and manage (tangible or intangible) resources that hold transformative potential, as they operate outside profit-making 
logics and use horizontal and participatory dynamics (De Angelis, 2018; Federici, 2018).

CMFs act as commons in the latter sense as tangible resources, i.e., facilities, that are self-managed in a participatory manner by non-profit grassroots organisations to carry out their own projects that seek to promote a more inclusive and democratic society (Pera, 2020). Some examples of these facilities in Barcelona are, among others, Casa Orlandai, a community/cultural centre that seeks to promote "social transformation through coexistence, respect and freedom," as well as to "build a more just society" (Casa Orlandai, 2020), and Casal de Barri Pou de la Figuera, a community centre that seeks to promote "social cohesion, equality, autonomy, and co-responsibility" (Casal Pou de la Figuera, 2020) through democratic participation that is open to all the many diverse social groups of the neighbourhood. However, as has been mentioned, CMFs are a particular type of commons, since their existence is based on the temporary transfer of the management of a public service by the City Council that has to be periodically renewed (generally every three years); in addition, the City Council subsidises CMFs to support the implementation of their projects financially.

It is likely that if we were to adopt a purist notion of commons, understood exclusively as "self-organising practices," we would not be able to study CMFs through this theoretical lens, because of the intrinsic relationship they maintain with the local state. However, the critical literature on the commons, especially on the urban commons, has increasingly pointed out that, in the dense and contested urban context, "we need to abandon a view that fantasises about uncontaminated enclaves of emancipation" (Stavrides, 2016, p. 56). This means that it is difficult to find commons that develop completely autonomously from their environment (Böhm et al., 2010; Narotzky, 2013), and that forms of institutional hybridisation are more widespread than is often thought. The literature on housing commons is an example of how the lens of the commons can be used to analyse initiatives that have an important component of self-organisation but that often represent forms of housing production and management that include both public and private actors, as well as public and private forms of ownership (Ferreri \& Vidal, 2020; Mullins et al., 2018). However, the hybrid nature of housing commons does not invalidate the practice of democratic and horizontal self-organisation that underpins them, nor does it invalidate the desire for de-commodifying these goods that drives these housing initiatives. Negotiations with private and public actors, using private forms of ownership, and being supported by public funding must be seen for what they are: strategies adopted by the different collectives to engender commons initiatives and keep them alive over time (Bianchi, 2018b; Huron, 2018).

Certainly, examining commoning practices that are enacted through hybrid institutional configurations poses additional analytical questions for our study.
The rationality and modalities of action that drive the commons is distinct from the rationality and modalities of action of state or market actors. Hence, the analysis of these hybrid commons configurations must pay particular attention to these differences and dissect the possible forms of tensions and frictions that might be produced by this kind of hybrid institutional nature. In our case, in fact, we are referring to commoning practices that have an ongoing relationship with the local state, because they are based on the City Council temporarily transferring the management of a public service, leading them to be deeply embedded in the local state's administrative norms and procedures. It is therefore the aim of this article to analyse what happens when these two divergent rationalities and modalities of action come together and, above all, how the local state's administrative norms and procedures influence the activity of these commoning practices, and if the commoning practices develop any forms of resistance, and how. We study the effect of these norms and procedures as well as the possibility of developing forms of resistance through the concept of governmentality.

\section{Governmentality and the State as Sites of Power}

Michel Foucault's studies in governmentality are part of his approach to the study of power. This investigates the diversity of forms and the multiplicity of sources of power, and the possibilities of resisting the application of power. Governmentality was defined by Foucault as "the ensemble constituted by the institutions, procedures, analyses, and reflections, the calculations and tactics that permit the exercise of this quite specific, albeit very complex form of power, which has, as its principal target population" (Foucault, 1979, p. 20). This ensemble represents a more or less calculated mentality-a governmentality-that directs and shapes the conduct of individuals for a variety of ends through different agencies-government, trade unions, non-profits, companies, and social institutions (Dean, 1999). Governmentality is enacted through technologies of power, i.e., intertwining coherent or contradictory forms of activating and managing a population (Donzelot, 1979), such as accountability, entrepreneurship and risk calculation. In short, governmentality is a form of exercising political power, which is not necessarily only reified in certain institutions such as the state, and that directs the conduct of individuals through specific technologies.

Foucault's reflections on governmentality have inspired a series of theoretical and empirical studies, especially in the English-speaking world, that have decentred the study of power from the state and have investigated ways of governing through a variety of practices spread throughout society (Dean, 1999; Lemke, 2002; Rose, 1999). These scholars have overcome conventional tenets in political science and Marxist studies that equate political power with state power and, 
instead, have incorporated the multiple and complex sites and forms of exercising power. One of the most studied fields has been the community as a new site of power (Rose, 1999). According to these studies, communities increasingly embody a new government territory "whose vectors and forces could be mobilised, enrolled, deployed in novel programmes and techniques which operated through the instrumentalisation of personal allegiances and active responsibilities" (Rose, 1996, p. 332). This led Rose to coin the expression "government through community."

The Foucault-inspired literature on community written in the English-speaking world has made an important contribution to understanding how practices of community involvement and citizen participation have been progressively used by different authorities to give individuals responsibility for their own destinies (Swyngedouw, 2005), to reduce their critical capacity since they are engaged in solving social problems without being called upon to analyse major structural problems, to normalise the retrenchment of the welfare state (Raco, 2000), to transform dissidence into a domesticated form of participation (Watkins, 2017), and so forth. Nevertheless, these studies, by adopting a Foucault-inspired decentring approach to the analysis of power, have tended to underestimate the role of the state: They refuse to "equate government with the state, understood as centralized locus of rule" and focus on decomposing power into microprocesses and elements applied to individuals (Jessop, 2010, p. 59). This tendency is due to an incomplete understanding of the concept of governmentality that, according to Jessop (2007), is not consistent with the evolution of Foucault's thought.

According to Jessop's critical review, Foucault's studies in governmentality were part of an intellectual journey that, although initially aiming to decentre the study of power from the state, returned to it by focusing on how state power is a crucial emergent field of strategic action (Jessop, 2010). In fact, Foucault (2009) identified three government dispositions through history: sovereignty, disciplinarity, and governmentality. The third one, the governmentalisation of the state, was fulfilled in the 19th century when the state focused on controlling the masses instead of controlling the territory as such. The idea of the governmentalisation of the state has provided stimulus to state scholars, who continue to see the state as a valid object of theoretical analysis and political practice, but aim to provide a critical and non-essentialist account of it in order to integrate the Foucauldian approach to governmentality into their perspectives (Jessop, 2007). The integration of the governmentality perspective into state theory implies delving into the multiple power relationships that crystallise within the state and its technologies of power but without considering the state as a unique and universal source of power (Jessop, 2007).

Finally, according to Foucault, resistance to governmentality and the corresponding technologies of power is possible, since rather than being monolithic and deterministic (Lentrichia, 1988; Wickham, 1986), power has a contingent relationship with resistance (Cortés Rodríguez, 2013; Driver, 1985; Pickett, 1996). In fact, Foucault (1987, p. 123) states that:

In the relations of power, there is necessarily the possibility of resistance, for if there were no possibility of resistance- of violent resistance, of escape, of ruse, of strategies that reverse the situation-there would be no relations of power.

In particular, Foucault envisaged resistance as an empirical and strategic response to concrete implementations of power, rejecting the existence of a universal ideal that could articulate and unify different struggles, such as justice (Cortés Rodríguez, 2013; Driver, 1985). The subjects to which the technologies of power are applied are not always completely docile, and "something always eludes the diffusion of power and expresses itself as indocility and resistance" (Pickett, 1996, p. 458). Indeed, the application of power can create circumstances that lead to resistance, for example, by creating huge factories where workers are submitted to disciplinary techniques, the conditions for a mass strike are also created (Pickett, 1996). Thus, we analyse whether any strategies of resistance are articulated in the CMFs in response to the bureaucratic and administrative processes applied by the City Council.

In sum, this article takes into account the relevant theoretical and empirical contributions of Englishspeaking Foucault-inspired scholars regarding community involvement and citizen participation, but also considers the state as one of the main sources of power that administers the population by applying technologies of power that seek to control and align individuals and collectives with the state's rationalities (Driver, 1985; Tilly, 1993). We focus on how the local state adopts specific technologies of power, administrative norms, and bureaucratic procedures to control and reshape the identity, activities, and projects developed in the CMFs. In addition, we consider the possibility of resisting technologies of power.

\section{Methodology}

The phenomenon of civic management in the city of Barcelona was used as a case study, with the multiple CMFs employed as sub-cases (Yin, 2014). The aim was to use a mixed approach to investigate the relationship between the City Council and the CMFs, identifying the aspects that have an effect on the everyday practices and structures of the CMF, which we divided into two areas: (a) administrative procedures related to accountability processes and (b) authorisation requests for the use of public space. The fieldwork took place in 2019 in two stages: The first phase was a questionnaire that was designed to record the main characteristics 
of the facilities, such as the year they were founded, their budgets, and their internal organisation. The second phase consisted of semi-structured interviews with grassroots members (mainly activists and some CMF workers) responsible for each facility, as well as politicians and public employees from the City Council. In this second phase, we focused on evaluating the experiences themselves and the relationship between the local state and the CMFs, identifying the administrative regulations and bureaucratic procedures that act as technologies of power, and examining the effects of these procedures on CMFs and on the associations that manage them.

In the first phase, of the 56 CMFs that existed in 2019, we received answers to our online questionnaire from 51. The results were analysed using descriptive statistics and enabled us to obtain a general description of the characteristics of the CMFs. In the second phase, $34 \mathrm{CMF}$ were selected from those that had answered the survey, considering their location and their type of activity. The criteria used for selecting the CMFslocation and type of activity-were chosen according to the diversity of the administrative areas of the municipality that the CMF established regular communication with and the processing of bureaucracy. The city of Barcelona is divided territorially into ten districts that have their own administrative structures, and in 2019 each had a certain degree of autonomy in the implementation of the agreements with the CMFs. Moreover, each area of activity-culture, sports, community development, youth, etc. - has its own administrative department and its own officials with whom the CMFs interact on a regular basis. Therefore, each CMF is principally related to its district as well as to the Department that corresponds to its scope of action. In this second phase we sampled $34 \mathrm{CMF}$, interviewing a total of 41 grassroots members and a total of seven public employees. The transcripts of the interviews were analysed qualitatively with Atlas.ti software.

\section{Administrative Procedures as Technologies of Power}

To use the concept of governmentality to illustrate the mechanisms implemented by the local state to monitor the CMFs, we describe and discuss the most common administrative procedures that result from the agreements established between the CMFs and the City Council. Firstly, we discuss local state regulations intended to ensure the accountability of the CMFs' activities. Secondly, we analyse the local state regulations related to requesting authorisation for using the public space. We focus on how these two types of administrative processes act as technologies of power and lead to the modification of the projects developed by the CMFs, hampering their transformative goals. Finally, we show some strategies of resistance that the CMFs have developed to invest more time and resources in their transformative goals.

\subsection{Accountability}

Each CMF signs an agreement with the City Council that is renewed approximately every three years; this specifies the cession of the facility to the grassroots organisation and the annual subsidy allocated to it. Consequently, the CMFs have to meet some requirements related to accountability. We refer to accountability as the external scrutiny of activities and decisions of an entity by the local state or an external agent, made to monitor, evaluate, and assess programmes that receive public funding or have an agreement with the City Council (Goodin, 2003). Accountability is a key element in democratic systems, and here we analyse the processes and instruments used to make CMFs accountable to the City Council.

The subsidies received by CMFs range from 18,000 to 250,000 euros depending on the facility and the project, and according to the results of the survey, money received as subsidies represent more than $50 \%$ of the total budget in $72 \%$ of the CMF. Spanish and Catalan subsidy laws all require CMFs to report all expenses incurred in detail, which turns to be a time-consuming task for CMF members. Moreover, CMFs often have to adapt their activities to comply with legal requirements, as expressed here by a member of a youth club in the Nou Barris district who complains about the fact that when they organise events, they cannot buy food at a supermarket but have to use a catering service instead:

There are many things that we would like to do differently, but the district administration doesn't approve of them. They prefer us to use a catering service instead of going to the supermarket to buy food, because they don't accept supermarket receipts as proof of payment.

In this case, for the youth club, having to use a catering service means, firstly, higher costs, and secondly, the loss of part of their own way of organising, as they are used to preparing food themselves and prefer to do it.

When the funding a CMF receives is greater than 30,000 euros, they are submitted to audits in which external private firms review the use of public money and the justification of it, according to the standards of the administration. The following quote is from a member of a CMF in the Sant Martí district and shows how the external audit process puts pressure on CMFs throughout the year, as they must generate invoices that meet the requirements of the City Council and have them prepared properly to the audit. Both are processes that require the time and resources of the CMF members:

Every year we have an audit. We have to present the statement of accounts. We have to report all, absolutely all the invoices of the entire budget, not only the subsidy from the City Council, but the entire budget. 
Secondly, the agreement with the City Council also defines the control and regulation procedures for the accountability of the activity performed. Each CMF has to provide periodic reports about the activity and, on an annual basis, a longer version that compares the reports with the CMF's projected work plan and projects. The termly reports mainly consist of quantitative indicators that measure the number of events held and other characteristics, such as the number of participants and their genders.

Respondents pointed out that the indicators demanded by the City Council are purely quantitative in nature and do not ask them about their community work, nor their commitment to strategies to create networks of reciprocity. Moreover, they argue that the indicators do not take into account the slower pace that non-professional organisations, such as CMFs, work at. In the following quote, a CMF member from the Eixample district explains their opinion and experiences with the metrics required by the City Council:

The City Council does not see civic management as a process and even less as citizen participation, in other words, they ask us for totally quantitative indicators, number of activities, number of people participating in the activities....This puts us in a tight spot, this imposes pressure on the people involved in participative activities....The CMF employee [who is hired to carry out the day to day tasks of the CMF] spends the whole day filling in metrics, she's always telling us that the date to send the activity data is getting nearer; it's all about numbers.

In this community centre, members feel pressurised by the quantitative indicators and feel they are pushed to relegating the work that centres on building bonds of reciprocity into second place, as well as modifying schedules they had envisioned. In addition, the interviewee points out how accountability metrics take valuable time away from the CMF employee, who could otherwise have been focussed on supporting CMF projects.

Moreover, the necessity of using these types of quantitative indicators tends to encourage the CMFs to schedule several events, prioritising the number of them rather than concentrating on activities that involve engaging with fewer participants on a longer-term basis. As the previous respondent pointed out:

We feel that for the City Council it's better to organize 20 activities rather than 10 , but we work with other principles: Neighbourhood engagement is achieved on a long-term basis.

The administrative procedures described so far-the financial and the activity reports-require CMF members to learn the codes, language, and methods that the administration uses. For instance, the quantitative indicators required to assess the CMF activity are the result of vertical formulas used to evaluate the performance of external actors that provide public services in a context of ever-increasing outsourcing of public services. These procedures "create new calculable spaces for experts to monitor and leaves partnerships open to quantitative assessment and funding discipline from above" (Raco \& Imrie, 2000, p. 2198)

These technologies of power are the result of the determination of the state at any level to increase its control over budget spending in favour of greater accountability to society (Raco \& Imrie, 2000), and to avoid fraudulent practices being carried out with public money (Shleifer \& Vishny, 1993). Whilst accountability is crucial in democratic systems, the mechanisms described here have been designed mainly for being applied to third sector organisations or companies that have a professionalised structures responsible for these processes, rather than the local grassroots groups studied here. There are other ways of evaluating grassroots activities; these are based on qualitative parameters that visualize long-term achievement such as building trust and ties, evaluation by external actors using ethnographic techniques and so forth (O'Dwyer \& Unerman, 2008).

\subsection{The Use of Public Space}

Another technology of power in the form of administrative procedures is the authorisation required to use public space. If CMFs wish to pursue any activities in the public space, such as cultural performances or workshops in a public square, they must request the corresponding permits. The grassroots members of the CMFs described frequent difficulties in processing authorisations. This often led to them having to cancel activities, or modify when or where they were held, in order to adapt them to the City Council's requirements. In the following quote, a CMF member from the Nou Barris district expresses how not being granted a permit complicates and slows down its aims of promoting citizens' self-organisation:

Some women from the neighbourhood have created a new feminist group linked to our CMF. Their first event was a cultural exhibition of flamenco dancing by some women from the neighbourhood in a public square, so they had to ask permission to use the square during the afternoon and the evening. The City Council refused permission on the grounds that we were already organising a lot of events here in the neighbourhood....This attitude undermines the motivation of people who have started to self-organise activities.

Furthermore, from the Sarrià-Sant Gervasi district, another CMF member illustrates how the refusal of a permit leads CMFs to change the location of their activities, which means they have to dedicate extra time to reformulate them: 
We wanted to hold an activity in the community garden next to the CMF, but they told us that we couldn't do it there, that we could only use the building.

The request for permits for the use of public space is not a technology of power deployed exclusively for controlling CMF activities, but also those of many other grassroots organisations. It should be contextualised in the reconfiguration of urban public spaces in global cities, in the planning and restructuring trends led by the public and private sector working together (Harvey, 1992; Raco, 2003). The tendency has consisted of a major commodification and securitisation of the public space, at the expense of politicised uses of it, which had included "a toleration of the risks of disorder as central to its functioning" (Mitchell, 1995, p. 115) and giving urban movements the possibility of making their demands public. The model has increased regulation of the practices that take place in the public space, sanctioning or excluding people that are considered in some way inappropriate, unimportant or as politically divergent, in favour of promoting the experience of the city as a spectacle (Delgado, 2011), where entertainment, consumption, and safety is encouraged above disruptive politics (Mitchell, 1995).

This paradigm has been applied to the city of Barcelona mostly through the adoption of a civic ordinance (Ajuntament de Barcelona, 2006). This ordinance has meant that CMF have to request authorisations and to comply with the norms stated within them when they carry out events in the public space; this often means having to reformulate activities. But most importantly, this kind of administrative procedure involves a significant investment of CMF members' time and resources to comply with them. In other words, from a governmentality approach, the local state uses the CMF members' time (with delays and reformulation procedures) as a monitoring strategy (Auyero, 2012).

To summarise, the application of technologies of power through administrative procedures related to accountability and the use of the public space have an impact on the transformative projects of CMF commons. They lead to the modification of the CMFs' activities, encourage the professionalisation of their structures and the adoption of state logics, such as a productivist vision of the activities organised, of the budget requirements, etc. In addition, complying with the necessary paperwork, dealing with delays, and the process of adaptation to the administration's codes all require the CMFs' members to invest time and resources, giving them less time to develop the more transformative and critical sides of their projects. Thus, commons such as CMFs that constantly have to relate with the local state may "feel pressured to forget their transformative goals in the interests of more productive partnerships with the state" (Watkins, 2017, p. 2145). In this way, the administrative procedures cause the CMF to run the risk of becoming part of a revisionist neoliberalism that uses local state procedures and norms to neutralise more transformative forms of association and to depoliticise them (Watkins, 2017).

\subsection{Strategies of Resistance}

While the application of technologies of power has been observed in all the CMF throughout the different districts of the city, their reactions to the threat of depoliticisation are diverse and have not so far generated coordinated action among CMFs. First, in some cases, the CMF members interviewed were barely aware of the phenomenon; they aimed to debate it collectively, but had not taken any counter-actions yet, as illustrated by a CMF member from the Sant Martí district:

This [the lack of time and resources to develop their project] is a recurrent debate that we have in different bodies of deliberation and participation with CMF members; we have mentioned it to the City Council, but there is some reluctance to admit it.

In other cases, when a permit to hold an activity in public space has been refused, a minority of the CMF interviewed opted to simplify the activity and carry it out without a permit, opening themselves up to sanctions from the City Council. However, this was perceived as a strategy for pursuing their objectives despite difficulties in processing authorisations.

Finally, one of the most common formulas to rationalise time and resources in order to carry out key activities was to create commissions that work exclusively on administrative procedures, supported by CMF workers. This strategy does not combat administrative procedures directly but does free up other CMF members' time so that they can focus on developing more transformative types of activities. The following quote, from a CMF member in the Sant Martí district, shows how this strategy has been adopted by a community centre:

Last April when I was the president, I saw that the management of the community centre was taking up a lot of the association's time, and we created a committee to manage the centre, and a committee for developing our project....With this division, we can do both things and separate the issues that belong to the management of the centre from the ones that belong to the association project.

The strategies of resistance employed by CMFs to avoid being fully reshaped by technologies of power show how, despite the substantial capacity of governmentality to hamper the performance of individuals and communities by the implementation of technologies of power, "dominant strategies do not occupy an empty landscape. They have to overcome resistances, refusals, and blockages" (Clarke, 2004, p. 44). The strategies implemented by CMFs do not directly confront the technologies of power identified in this article, neither do they dismantle 
them. The mechanisms of resistance observed in CMFs focus on escaping from co-optation mechanisms in order to continue with their transformative goals. Foucault (1987) considered escaping from technologies of power or even using them as forms of resistance to attempt to reverse the situation. Thus, our analysis shows that the City Council's technologies of power that aim to control and co-opt the CMFs are not wholly successful: Some critical discourses persist and encourage hybrid institutional commons to explore different ways of continuing with their transformative goals.

\section{Conclusion}

CMFs represent a particular case of commons, since they are public facilities that have been transferred to grassroots organisations and, therefore, must maintain an ongoing relationship with the local state. We have conceptualised these commoning practices as hybrid forms of commons, i.e., commons that are enacted through hybrid institutional configurations (Ferreri \& Vidal, 2020; Mullins et al., 2018). With this article we aim to further the knowledge on these hybrid forms of commons by exploring the political tensions that may unfold when different rationalities and modalities of action, such as those of the commons and those of the state, need to co-exist under the same institutional umbrella. We have examined these contingent political tensions that CMFs experience through the concept of governmentality, analysing how the transformative projects developed by hybrid forms of commons located in Barcelona are affected by a series of technologies of power used by the local state, namely administrative norms and procedures such as accountability processes, and if and how forms of resistance are developed by commons' members. The analysis has shown that when commons are enacted that have hybrid institutional configurations, contingent political tensions unfold.

On the one hand, the local state deploys administrative norms and procedures as technologies of power to control and redirect the actions of these commons. They do so by absorbing the working time of members who must comply with these norms and procedures and cannot devote themselves to organising activities through which they pursue transformative projects; they also do so by directly changing or influencing the rationality and mode of developing these activities. The reason for the technologies of power seems, in the first instance, to stem from a need to apply procedures of control and accountability to their activities. Nevertheless, these technologies of power also act as an attempt by the local state to co-opt the transformative potential of these commons. The analysis also shows how the commons can articulate some forms of resistance, which, although they do not directly contest these technologies of power, are used to reduce the local state's co-optation effects so that the commons can continue to pursue their transformative goals.
The tensions that have risen within these hybrid forms of commons-between grassroots organisations and the local state-seem almost inevitable and are difficult to resolve due to the different natures, objectives, and rationalities of the actors involved, as well as the local state's power and capacity to rule (Böhm et al., 2010). Both actors benefit from the public-commons collaboration, which for the CMF means stability and economic capacity for developing their projects, and for the local state means an innovative form of citizen participation and service provision (Blanco, 2021). Thus, we believe this article underscores the need to explore new forms of governing the idiosyncrasies of hybrid forms of commons to limit the effects of the technologies of power. For instance, the City Council, in cooperation with civil society organisations, including some CMFs, have recently been working on a new set of criteria to evaluate community-based projects such as CMFs: The plan is to implement them gradually over the next few years. This evaluation is called balanç comunitari ("community balance") and includes criteria proposed by grassroots organisations themselves and later adopted by the City Council, such as social impact and return, local bonds, internal democracy and participation, quality of work, and environmental sustainability (Ajuntament de Barcelona, 2020).

The community balance is only one of the many different strategies possible; other tools can be constructed to govern the idiosyncrasies of hybrid forms of the commons. What we intend to emphasise with this example is that possibilities do exist to govern this phenomenon, ones that can allow community projects that materialise through a hybrid form of commons to continue to pursue their transformative objectives. However, these forms of governing the hybrid forms of commons cannot be developed without a firm commitment from the grassroots organisations themselves, which must include this push within their own strategies of resistance.

Regarding resistance strategies articulated by CMFs, we have observed that they are a contingent reaction to the implementation of technologies of power, developed in order to fulfil their transformative goals. However, they do not directly confront technologies of power. A long-term perspective is needed to evaluate to what extent these strategies enable the development of the CMFs' transformative goals and reverse the effect of the City Council's technologies of power. Moreover, a long-term perspective would also allow us to evaluate whether these resistance strategies can evolve into other forms of struggle that might lead to situations of conflictual cooperation (Giugni \& Passy, 1998) between the CMFs and the City Council.

In conclusion, we think that this work contributes to informing commons theory in a broader fashion, since it is rarely possible for commons to achieve autonomy in capitalist societies (Böhm et al., 2010; Narotzky, 2013). Many urban commons find themselves entering relationships with the state, sometimes to ask for 
financial support, sometimes to demand the cession of a space, among other reasons (Bianchi, 2018b). The application of the Foucauldian perspective of governmentality enables scholars to analyse contradictory rationalities, the implementation of technologies of power, and the process of co-optation that commons can experience when they take on a hybrid institutional form. Moreover, the study of commons from a Foucauldian approach does not exclude the possibility of the commons reacting in order to resist the processes that exert power.

\section{Acknowledgments}

We would like to express our gratitude to the editors and the anonymous reviewers for the rigorous comments we received in the process of writing this piece. We would also like to thank Prof. Ismael Blanco for his invaluable revision. The research was supported by a PhD grant from the Autonomous University of Barcelona. The publication costs have been carried by the Institute of Government and Public Policy (IGOP-UAB) and the Foundation Studio for International Development, Amsterdam. Finally, our sincere gratitude goes to the interviewees who agreed to share their time and their experiences with us. Although both authors are jointly responsible for this article, Iolanda Bianchi is the sole author of Section 2, while Sections 4 and 5 were written by Marina Pera. The two authors wrote Sections 1, 3, and 6 together.

\section{Conflict of Interests}

The authors declare no conflict of interests.

\section{References}

Ajuntament de Barcelona. (2006). Ordenança de mesures per fomentar $i$ garantir la convivència ciutadana a l'espai públic de Barcelona [Ordinance of measures to promote and guarantee the citizen coexistence in public space in Barcelona]. https:// ajuntament.barcelona.cat/dretsidiversitat/sites/ default/files/Convivencia.pdf

Ajuntament de Barcelona. (2020). Participació ciutadana. Patrimoni ciutadà [Citizen participation. Citizen assets]. https://ajuntament.barcelona.cat/ participaciociutadana/ca/patrimoni-ciutada

Andreu Acebal, M. (2014). El moviment ciutadà i la transició a Barcelona: La FAVB (1972-1986) [Citizen movement and political transition in Barcelona: The FAVB (1972-1986)] [Doctoral thesis, University of Barcelona]. TDX Repository. http://www.tdx.cat/ handle/10803/134795

Auyero, J. (2012). Patients of the state. Duke University Press.

Bianchi, I. (2018a). Dal Pla Buits al patrimonio cittadino di uso e gestione comunitaria [From the Vacant Plot plan to the citizen assets programme]. In E. Ostanel
(Ed.), Spazi fuori dal Comune: Rigenerare, includere, innovare [Spaces out of the common: Rigenerating, including, innovating] (pp. 52-57). Franco Angeli.

Bianchi, I. (2018b). A relational approach for the study of urban commons: The case of the Escocesa Art Centre in Barcelona. Tracce Urbane: Italian Journal of Urban Studies, 4, 171-193. https://doi.org/10.13133/25326562_2.4.14356

Bianchi, I. (2018c). The post-political meaning of the concept of commons: The regulation of the urban commons in Bologna. Space and Polity, 22(3), 287-306. https://doi.org/10.1080/13562576.2018.1505492

Blanco, I. (2021). Social innovation against socio-spatial segregation: The case of Catalonia. In L. Fregolent \& O. Nel·lo (Eds.), Social movements and public policies in Southern European cities (pp. 113-135). Springer.

Böhm, S., Dinerstein, A. C., \& Spicer, A. (2010). (Im)possibilities of autonomy: Social movements in and beyond capital, the state and development. Social Movements Studies, 9(1), 17-32.

Casa Orlandai. (2020). Associació cultural Casa Orlandai. Descàrregues: Memòria abreujada [Cultural association Casa Orlandai. Downloads: Brief memory]. https://casaorlandai.cat/descarregues

Casal Pou de la Figuera. (2020). Casal de Barri Pou de la Figuera: El casal [Casal de Barri Pou de la Figuera: The center]. http://casalpoudelafiguera.net/el-casal

Clarke, J. (2004). Dissolving the public realm? The logics and limits of neo-liberalism. Journal of Social Policy, 33(1), 27-48.

Cortés Rodríguez, M. A. (2013). Poder y resistencia en la filosofía de Michel Foucault [Power and resistance in the philosophy of Michel Foucault]. Biblioteca Nueva.

Dalmau, M., \& Miró, I. (2010). Les cooperatives obreres de Sants: Autogestió proletària en un barri de Barcelona (1870-1939) [The workers cooperatives of Sants: Proletarian self-organization in a neighbourhood of Barcelona (1870-1939)]. La Ciutat Invisible.

De Angelis, M. (2018). Omnia sunt communia: On the commons and the transformation to postcapitalism. Zed Books.

Dean, M. (1999). Governmentality: Power and rule in modern society. SAGE.

Delgado, M. (2011). El espacio público como ideología [Public space as ideology]. Los libros de la Catarata.

Donzelot, J. (1979). The policing of families. The Johns Hopkins University Press.

Driver, F. (1985). Power, space and the body: A critical assessment of Foucault's Discipline and Punish. Environment and Planning D: Society and Space, 3, 425-446.

Enright, T., \& Rossi, U. (2018). Ambivalence of the urban commons. In K. Ward, A. E. G. Jonas, B. Miller, \& D. Wilson (Eds.), The Routledge handbook on spaces of urban politics (pp. 35-46). Routledge.

Federici, S. (2018). Re-enchanting the world: Feminism and the politics of the commons (Vol. 12). PM Press.

Ferreri, M., \& Vidal, L (2020). Public-cooperative pol- 
icy mechanisms for housing commons. International Journal of Housing Policy. https://doi.org/10.1080/ 19491247.2021.1877888

Foucault, M. (1979). Power, truth, strategy. Feral Publication.

Foucault, M. (1987). The ethic of care for the self as a practice of freedom. Philosophy and Social Criticisms, $12(2 / 3), 112-131$.

Foucault, M. (2009). Security, territory, population: Lectures at the College de France, 1977-1978. Palgrave Macmillan.

García, M., Eizaguirre, S., \& Pradel, M. (2015). Social innovation and creativity in cities: A socially inclusive governance approach in two peripheral spaces of Barcelona. City, Culture and Society, 6(4), 93-100.

Giugni, M., \& Passy, F. (1998). Contentious politics in complex societies: New social movements between conflict and cooperation. In M. Giugni, D. McAdam, \& C. Tilly (Eds.), From contention to democracy (pp. 81-107). Rowman \& Littlefield.

Goodin, R. E. (2003). Democratic accountability: The distinctiveness of the third sector. Archives Europeennes de Sociologie, 44(3), 359-396.

Harvey, D. (1992). Social justice, postmodernism and the city. International Journal of Urban and Regional Research, 16, 588-601.

Harvey, D. (2012). Rebel cities: From the right to the city to the urban revolution. Verso.

Hess, C., \& Ostrom, E. (2007). Understanding knowledge as a commons. From theory to practice. MIT Press.

Huron, A. (2018). Carving out the commons: Tenants organising and housing cooperatives in Washington, $D C$. Minnesota University Press.

Jessop, B. (2007). From micro-powers to governmentality: Foucault's work on statehood, state formation, statecraft and state power. Political Geography, 26(1), 34-40.

Jessop, B. (2010). Constituting another Foucault effect. Foucault on states and statecraft. In U. Bröckling, S. Krasmann, \& T. Lemke (Eds.), Governmentality: Current issues and future challenges (pp. 56-73). Routledge.

Lemke, T. (2002). Foucault, governmentality, and critique. Rethinking Marxism, 14(3), 49-64.

Lentrichia, F. (1988). Ariel and the police: Michel Foucault, William James, Wallace Stevens. University of Washington Press.

Mayer, M. (2013). First world urban activism. City, 17(1), 5-19.

Mitchell, D. (1995). The end of public space? People's park, definitions of the public, and democracy. Annals of the Association of American Geographers, 85(1), 108-133.

Mullins, D., Milligan, V., \& Nieboer, N. (2018). State directed hybridity? The relationship between nonprofit housing organizations and the state in three national contexts. Housing Studies, 33(4), 565-588.

Narotzky, S. (2013). What kind of commons are urban commons? Focaal: Journal of Global and Historical
Anthropology, 66, 122-124.

O'Dwyer, B., \& Unerman, J. (2008). The paradox of greater NGO accountability: A case study of Amnesty Ireland. Accounting, Organizations and Society, 33, 801-824.

Ostrom, E. (1990). Governing the commons: The evolution of institutions for collective action. Cambridge University Press.

Pera, M. (2020). Potential benefits and challenges of the relationship between social movements and the commons in the city of Barcelona. Ecological Economics, 174. https://doi.org/10.1016/j.ecolecon. 2020.106670

Pickett, B. L. (1996). Foucault and the politics of resistance. Polity, 28(4), 445-466.

Raco, M. (2000). Assessing community participation in local economic development: Lessons for the new urban policy. Political Geography, 19(5), 573.

Raco, M. (2003). Remaking place and securitising space: Urban regeneration and the strategies, tactics and practices of policing in the UK. Urban Studies, 40(9), 1869-1887.

Raco, M., \& Imrie, R. (2000). Governmentality and rights and responsibilities in urban policy. Environment and Planning A, 32(12), 2187-2204.

Rose, N. (1996). The death of the social? Re-figuring the territory of government. Economy and Society, 25(3), 327-356.

Rose, N. (1999). Powers of freedom: Reframing political thought. Cambridge University Press.

Sánchez Belando, M. V. (2015). Las políticas culturales de proximidad en el paradigma de la ciudad creativa: El caso del programa de centros cívicos en la ciudad de Barcelona [The proximity cultural policies in the creative city paradigm: The case of civic centre programs in the city of Barcelona]. Política y Sociedad, 52(1), 125-152.

Shleifer, A., \& Vishny, R. W. (1993). Corruption. Quarterly Journal of Economics, 108(3), 599-617.

Solà, P. (1978). Els ateneus obrers i la cultura popular a Catalunya (1900-1939): L'ateneu enciclopèdic popular [The workers atheneum and popular culture in Catalonia (1900-1939)]. Edicions La Magrana.

Stavrides, S. (2016). Common space: The city as commons. Zed Books.

Swyngedouw, E. (2005). Governance innovation and the citizen: The Janus face of governance-beyond-thestate. Urban Studies, 42(11), 1991-2006.

Tilly, C. (1993). Coercion, capital, and European states. Blackwell.

Watkins, H. M. (2017). Beyond sweat equity: Community organising beyond the Third Way. Urban Studies, 54(9), 2139-2154.

Wickham, G. (1986). Power and power analysis: Beyond Foucault? In M. Gane (Ed.), Towards a critique of Foucault. Routledge.

Yin, R. K. (2014). Case study research: Design and methods. SAGE. 


\section{About the Authors}

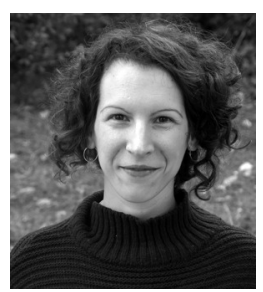

Marina Pera is a PhD candidate at the Institute of Government and Public Policy (IGOP) and the Political Science Department at the Autonomous University of Barcelona. She holds an MA in sociology from Columbia University, New York. Her main lines of research are urban commons, coproduction policies, and community development. Her dissertation analyses civic management facilities as practices that contribute to democratic governance, community cohesion, and awareness of power relations.

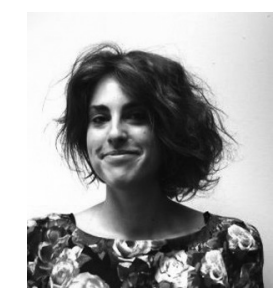

Iolanda Bianchi (PhD in political science and $\mathrm{PhD}$ in urban planning) is an urban political scholar. She currently holds a Juan de la Cierva postdoctoral researcher position at the Institute of Government and Public Policy (IGOP) at the Autonomous University of Barcelona. Her research focuses on the interplay between civil society and public action in the urban context, so that basic needs are met and fundamental rights ensured, and uses a critical approach to urban governance, urban politics, public policies, and commons studies. 